I I UC STUDI ES

ISSN 1813-7733

Vol. - 3, December 2006 (p 63-72)

\title{
The need of Uniform Islamic Constitution for the Muslim Ummah: A study of Islamic provisions on the Constitution of selected countries.
}

\begin{abstract}
Md. Abdul Awal Khan*
Abstract: Islam is a complete code of life as stated in the holy Quran (3:19), which is the prime source of Islamic Constitution. Al-Quran, therefore, regulates the life of a human being and Constitution for the Muslim Ummah to govern their country. Hazrat Muhammad (sm) taught the Muslims to maintain, preserve, consolidate and to strengthen fraternal relations and unity among Muslims which was extended to the Khulafa-e-Rashedin regime and then Abbasid and Osmania Khilafat. At that time Muslim states were governed according to the provisions of Al-Quran and Sunnah. But at present, the Muslim Countries have departed from the Al-Quran and Sunnah. Muslims Ummah lost its central power with the end of Osmania Khilafat. Later many Muslim territory became independent one after another but they imposed more importance on geographical position, language, culture and history rather than Islam. They included in their Constitution secular, socialist, capitalist ideology and they touched some Islamic provisions in their Constitution just to give it Islamic colour. Many Muslim states have enacted many anti-Islamic provisions in their Constitution too. This article is aimed at finding and highlighting such provisions and to make a comparison among selected Constitutions of Muslim states. This article also suggests the Muslim states to enact uniform Constitution for the Muslim Ummah.
\end{abstract}

\section{Introduction}

Every country has its Constitution but this doesn't necessarily imply that every country in the world is endowed with a Constitutional government or the practice of constitutionalism $^{1}$. It doesn't mean that Constitution is unnecessary thing of the state. Every country must have a Constitution, which is the governing wheel of the state. ${ }^{2}$ Government without a Constitution is power without a right. ${ }^{3}$ It is system of law established by a sovereign state for its own guideline. ${ }^{4}$ It reflects the philosophy, ideality and nature of the country. The nature of Constitution depends on the very mentality of the lawmakers of a country. It is the way of life the state has chosen for itself. ${ }^{5}$ It is the supreme law of the state containing the principles upon which the Government is founded, regulating the division of sovereign powers and directing to what persons each of these powers is to be confined and the manner in which it is to be exercised. ${ }^{6}$ Constitution is also said as collection of principles according to which the powers of the governed and the relation between them are adjusted. ${ }^{7}$. The theme of the Constitution varies from country to country on the basis of their principles. The nature of the secular and socialist Constitution is quiet different from Islamic or other religious Constitution.

\section{Concept of Islamic Constitution, Islamic states and Muslim states}

Islamic constitution is that constitution where "Islamic Shariah forms the law of the land and the Holy Quran and Sunnah are the main sources and guidelines of the state and on the basis of this principle, state enacts Islamic constitution. There shall be no such legislation as would contravene any of the principle of the Shariah. All laws, which are in

* Lecturer, Department of Law, International Islamic University Chittagong. 


\section{IIUC Studies, Vol. 3}

conflict with the principles of the shariah, shall not be included. It is incumbent upon the state to eradicate the vices which Islam wants to eradicate and to uphold and enforce the virtues which Islam requires to be uphold and enforced."8 There are about 56 Muslim states in the world but among them, very few states so far have framed Islamic Constitution. It is only Iran, which has enacted Islamic Constitution in 1982. A Muslim state, which has inserted Islamic provisions in its Constitution and exercises this strictly, is called Islamic state, but a Muslim states is one, which has Muslims majority, but no Islamic Constitution. So it is said that all Islamic states are Muslim states but all Muslim states are not Islamic states. Bangladesh, Qatar, Saudi Arabia, Malaysia etc. are Muslim states but Iran is an Islamic state.

\section{Sources of Constitutional Law}

Legislation, judge-made laws, conventions and practices are the sources of Constitutional law. The authoritative books on Constitutional law can be treated as source of Constitutional law but they have persuasive force only. ${ }^{9}$

\subsection{Sources of Islamic Constitutional Law}

There are at least six sources of Islamic Constitution, such as Al-Quran, Al-Sunnah, Conventions of rightly guided Caliphs, rulings of great jurists, Constitution of Medina and Constitution of some contemporary Islamic states. ${ }^{10}$

\subsection{Peoples Republic and Islamic Republic}

Republic is a form of Government in which sovereign powers rest with the people either with the entire body of active citizens or with a major part of it. ${ }^{11}$ So in Peoples' Republic is where people are the source of sovereign power of the state. On the other hand, in Islamic Republic, Allah is the source of sovereign power.

\subsection{Secularism and Islam}

Secularism is an ethical system founded on the principles of natural morality and independent of revealed religion or supernaturalism ${ }^{12}$. Secularism is free from any religious touch, which is opposed to the view of Islam.

\subsection{Monarchy and Islam}

Islam supports democracy and opposes autocracy and monarchy. The Head of the state of Islamic state is elected ${ }^{13}$ Almighty Allah revealed many verses against monarchy in several places of the Holy Qur'an. "They are those who if we establish them in the land, establish regular prayer and give zakat, enjoin the right and forbid the wrongs."14 These persons are appointed through democratic process and act as representative of Almighty Allah. Again, Allah said " that home of the hereafter we shall give to those who intend not high handedness or mischief on earth"15. Allah says against Kingship or monarchy. "Kings when they enter a country despoil it and make noblest thus do they behave"16. Again He says, "as for the boat it belonged to certain men in dire want. They piled on the water. I but wished to render it unserviceable, for there was after them a certain King who seized on every boat by force." ${ }^{, 17}$ So Al-Quran is against monarchy but at present many Muslim states are ruled by monarchs. Kingdom of Saudi Arabia is a glaring example.

\subsection{Sovereignty in Islam}

“Sovereignty' is derived from the Latin word supernuus which means supreme. The definition of the term is varied but "it always signifies the highest governmental and legal authority of some sort." ${ }^{\prime 8}$ The attributes and characteristics of sovereignty are said to be permanence, exclusiveness, all-comprehensiveness, indivisibility and absoluteness. ${ }^{19}$ "If a person or a group of persons or an institution is to be sovereign, it would mean that the 


\section{The need of Uniform Islamic Constitution for the Muslim Ummah}

word of that person, group or institution is law. A Sovereign has the unquestionable right to impose his orders on all subjects of the State and the subjects are under an absolute obligation to obey him, be it willingly or unwillingly. No outside agency, excepting his own will, imposes any limitations or restrictions on his power to rule. No subject has any absolute right against him or in contravention of his orders. ${ }^{20}$ It is exactly for this reason that whenever the experts of Political Science, imbued with this ideological sense of sovereignty, had endeavored to locate the possessor of such sovereignty in human society, they have invariably failed. For they can find nobody of the size whom this cap would fit - that is, nobody from amongst the human beings. Even in the entire gamut of creation, there is no creature who can rightly claim to possess all the attributes of sovereignty. ${ }^{21}$."But in the political sphere, and with respect to men or agencies, in charge of guiding people towards their earthly destinies, there is no valid use of Sovereignty. If the State is accountable and subject to the supervision, how can it be sovereign? What can possibly be the concept of sovereignty liable to supervision and accountability? Clearly, the State is not sovereign, nor are the people. Nor do they exercise a power without accountability ....... the power they exercise, either by mass reflexes and extra-legal means or through regular channels of a truly democratic society is in no way a power without accountability"22. The Quran stresses in many verses regarding sovereignty of Allah who is omnipotent, All-powerful. ${ }^{23}$ He has to refer to none and to render account to none. ${ }^{24} \mathrm{He}$ is the source and fount of all authority. ${ }^{25} \mathrm{He}$ is the only one whose authority and power nothing can limit or restrain ${ }^{26}$ and He alone is above all aberration and error. ${ }^{27}$ "Verily, His is the Creation and His is the Law. ${ }^{28}$ And those who do not make their decisions in accordance with that revealed by Allah are (in fact) the unjust. ${ }^{29}$ The Command is for none but Allah He hath commanded that ye obey none but Him: that is the right path. ${ }^{30}$ Follow the revelation sent unto you from your Lord, and do not follow the ( so-called) guardians other than Him. ${ }^{31}$ And those who do not make their decisions in accordance with that revealed by Allah are (in fact) the disbelievers. ${ }^{32}$ In law, sovereignty implies an unqualified power of enacting, amending or repealing laws. Constitution or legislature in an Islamic country is not sovereign in that sense because it doesn't have the power to make any law that it likes. That power being limited by the restrictions imposed by Islam on law making which are permanent, can't be removed by any process of legislation. ${ }^{33}$ This concept of sovereignty i.e. absolute sovereignty belongs to Allah, which is followed in the Islamic Constitution.

\section{Medina Charter}

'The Medina Charter is regarded as the first written Constitution in the annals of the world. Before the Prophet of Islam, many rulers ruled but none gave such a written Constitution. The Charter may also be called the Magna Carta of early Islam. It announced the great principles of equality, freedom of worship and religious tolerance. It was Muhammad (Sm) who, for the first time, realized the importance of the people's cooperation and goodwill in the administration of the country. The Charter proves that Muhammad (Sm) was not only a religious preacher, but also one of the greatest statesmen the world has ever produced. ${ }^{34}$. According to W. Muir " it reveals the man in his real greatness a master-mind, not only of his own age but of all ages.” 35

\section{Nature of the Constitution of Bangladesh}

Constitution of Bangladesh is neither Islamic Constitution nor secular. About 85\% people of Bangladesh are Muslims. Bangladesh is a democratic state. Secularism, Socialism, Communism is opposed to the Islamic view but that provisions were present in the preamble of the Constitution of Bangladesh 1972. Declaring the people to be the source of all power, Constitution, referred to the nationalism, socialism, democracy and 


\section{IIUC Studies, Vol. 3}

secularism as the fundamental principles ${ }^{36}$. Later secularism was omitted and an explanation was added in the meaning of the socialism as economic and social justice. ${ }^{37}$. The Constitution of 1974 abolished all political parties along with all parties based on religion ${ }^{38}$ but all anti-Islamic provisions were repealed by the Fifth Amendment.

\subsection{Islamic provisions in the Constitution of Bangladesh}

Though there are some Islamic provisions in the Constitution of Bangladesh, these are not followed. "Bismillahir Rahmanir Rahim" means "In the name of Allah the Beneficent, the Merciful" was inserted in the beginning of the Constitution. "Pledging that the high ideals of absolute trust and faith in the Almighty Allah..............shall be the fundamental principles of the Constitution" ${ }^{40}$. The state religion of the Republic is Islam but other religion may be practiced in peace and harmony in the Republic ${ }^{41}$."The principles of absolute trust and faith in the Almighty Allah shall constitute the fundamental principles of state policy." "22 Again "Absolute trust and faith in the Almighty Allah shall be the basis of all actions. ${ }^{43}$. The State shall .......... prevent the consumption of alcohol except for medical purposes or for other purposes as may be prescribed by law of alcoholic and other intoxicating drinks and of drugs which are injurious to health. ${ }^{44}$ The state shall adopt effective measures to prevent prostitution and gambling. ${ }^{45}$ The State shall endeavour to consolidate, preserve and strengthen fraternal relations among Muslim countries based on Islamic solidarity. ${ }^{46}$

\subsection{Islamic feature of the Constitution of Pakistan}

Constitution of Pakistan starts with "Bismilla----------Rahim" and the name of Pakistan Constitution is Constitution of Islamic Republic of Pakistan. Sovereignty over the Universe belongs to Almighty Allah alone and the authority to be exercised by the people of Pakistan with the limits prescribed by Him is a sacred trust . Principles of democracy, freedom, equality, tolerance and social justice as enunciated by Islam shall be fully observed, the Muslims shall be enabled to order their lives in the individual and collective spheres in accordance with the teaching and requirements of Islam as set out in the Holy Quran and Sunnah. ${ }^{47}$ Pakistan is a Federal Republic in which the Supreme Power is vested in the people and exercised through their elected representatives. ${ }^{48}$ Islam is the state religion of Pakistan and every citizen has the right to profess, practice, and propagate his religion and every religion denomination and every sector thereof has the right to establish, maintain and manage its religious institutions ${ }^{49}$. No person shall be compelled to pay any special task the proceeds of which are to be spent on the propagation or maintenance of any religion other than his $\mathrm{own}^{50}$. No person attending any educational institution shall be required to receive religion instruction or task pant in any religion ceremony or attend religion worship related to a religion other than his $\mathrm{own}^{51}$.It enables the Muslims of Pakistan individually and collectively to order their lives in accordance with the fundamental principles and basic concepts of Islam and to provide facilities whereby they may be enabled to understand the meaning of life according to the Holy Quran and Sunnah. The state shall endeavor as respects the Muslims of Pakistan to make the teaching of the Holy Quran and Islamiat is compulsory to encourage and facilitate the learning; Arabic language and to secure correct and exact printing and publishing of the Holy Quran; to promote unity and observance of the Islamic moral standards and to secure the proper organization of zakat, auqaf and mosques ${ }^{52}$.The state shall endeavor to preserve and strengthen fraternal relation, unity, support the common interest of the peoples of Asia, Africa and Latin America, promote international peace and security foster good will and friendly relations among all nations and encourage the settlement of international disputes by peaceful means. ${ }^{53}$ The President of Pakistan shall be Muslim ${ }^{54}$. Existing laws shall be brought in conformity with the injunction of Islam as 


\section{The need of Uniform Islamic Constitution for the Muslim Ummah}

laid down in the Holy Quran and Sunnah. No laws shall be enacted which is repugnant to such injunctions. These provisions shall not affect the personal laws of non-Muslims citizens of their status as citizens. ${ }^{55}$ Pakistan Constitution composed of Islamic council whose member should be very much expert in the principle and philosophy of Islam as enunciated in the Holy Quran and Sunnah. "Constitution of Pakistan represents a combination of Islamic and socialistic thoughts but is named Islamic Republic of Pakistan. Ahmadies were declared in the Interpretation chapter of Second Amendment as non-Muslims. Its effect is confirmed to declaring person with certain beliefs as nonMuslims."

\subsection{Nature of the Constitution of Islamic Republic of Iran}

The Constitution of Iran is called exclusively Islamic Constitution. Some verses of the Holy Quran are inserted in the Constitution. The form of government of Iran is that of an Islamic Republic, endorsed by the people of Iran on the basis of their longstanding belief in the sovereignty of truth and Qur'anic justice. ${ }^{57}$ The Islamic Republic is a system based on the following:

1. The one God (as stated in the phrase "There is no God except Allah"), His exclusive sovereignty and the right to legislate, and the necessity of submission to His commands;

2. Divine revelation and its fundamental role in setting forth the laws;

3. The return to God in the Hereafter, and the constructive role of this belief in the course of man's ascent towards God;

4. The justice of God in creation and legislation;

5. Continuous leadership (imamah) and perpetual guidance, and its fundamental role in ensuring the uninterrupted process of the revolution of Islam;

6. The exalted dignity and value of man, and his freedom coupled with responsibility before God; in which equity, justice, political, economic, social, and cultural independence and national solidarity are secured by recourse to:

(a) Continuous ijtihad of the fuqaha' possessing necessary qualifications, exercised on the basis of the Qur'an and the Sunnah of the Ma'sumun, upon all of whom be peace;

(b) sciences and arts and the most advanced results of human experience, together with the effort to advance them further;

(c) negation of all forms of oppression, both the infliction of and the submission to it, and of dominance, both its imposition and its acceptance. $^{58}$

In accordance with the command of the Qur'an contained in the verse ("Their affairs are by consultations among them" [42:38]) and ("Consult them in affairs" [3:159]), consultative bodies - such as the Islamic Consultative Assembly, the Provincial Councils, and the City, Region, District, and Village Councils and the likes of them - are the decision-making and administrative organs of the country. ${ }^{59}$ The conditions, limits, and nature of the duty of the Republic of Iran will be specified by law. This is in accordance with the Qur'anic verse; "The believers, men and women, are guardians of one another; they enjoin the good and forbid the evil" [9:71] ${ }^{60}$ In accordance with the sacred verse of the Qur'an, "This your community is a single community, and I am your Lord, so worship Me" [21:92], all Muslims form a single nation, and the government of the Islamic Republic of Iran has the duty of formulating its general policies with a view to cultivating the friendship and unity of all Muslim people, and it must constantly strive to bring about the political, economic, and cultural unity of the Islamic world. ${ }^{61}$ In 


\section{IIUC Studies, Vol. 3}

accordance with the sacred verse, "God does not forbid you to deal kindly and justly with those who have not fought against you because of your religion and who have not expelled you from your homes" [60:8], the government of the Islamic Republic of Iran and all Muslims are duty-bound to treat non-Muslims in conformity with ethical norms and the principles of Islamic justice and equity, and to respect their human rights. This principle applies to all who refrain from engaging in conspiracy or activity against Islam and the Islamic Republic of Iran. ${ }^{62}$ These are the main Islamic provisions of the Constitution of Iran and it is called the only proper Islamic Constitution of the world.

\subsection{Nature of the Constitution of Kingdom of Saudi Arabia}

Though the Constitution of the Kingdom of Saudi Arabia is not exclusively Islamic, but it has some Islamic provisions. The Kingdom of Saudi Arabia is a sovereign Arab Islamic state with Islam as its religion based on God's Book and the Sunnah of His Prophet. ${ }^{63}$ Rule passes to the sons of the founding King, Abd al-Aziz Bin Abd al-Rahman al-Faysal Al Sa'ud, and to their children's children. Allegiance to the Holy Quran and the tradition of the Prophet is the basic principle of the Constitution. ${ }^{64}$ Government in Saudi Arabia derives power from the holy Quran and the Prophet's tradition. ${ }^{65}$ Government in the Kingdom of Saudi Arabia is based on the premise of justice, consultation and equality in accordance with the Islamic Shari'ah. ${ }^{66}$ The family is the kernel of Saudi society, and its members shall be brought up on the basis of the Islamic faith, and loyalty and obedience to God, His Messenger, and to guardians; respect for and implementation of the law, and love of and pride in the homeland and its glorious history as the Islamic faith stipulates. ${ }^{67}$ Saudi society will be based on the principle of adherence to God's command. ${ }^{68}$ Property, capital, and labour are maintained in accordance with Islamic Shari'ah. ${ }^{69}$ The state protects Islam; it implements its Shari'ah; it orders people to do right and shun evil; it fulfills the duty regarding God's call. ${ }^{70}$ The state protects human rights in accordance with the Islamic Shari'ah. ${ }^{71}$ Islamic penology is followed in Saudi Arabia. Penalties shall be personal and there shall be no crime or penalty except in accordance with the Shari'ah. ${ }^{72}$ The source of the deliverance of fatwa in the Kingdom of Saudi Arabia is God's Book and the Sunnah of His Messenger. The law will define the composition of the senior ulema body, the administration of scientific research, deliverance of fatwa and it's (the body of senior ulema's) functions ${ }^{73}$. The judiciary and court proceedings are also regulated by the provisions of Shariah and Sunnah. ${ }^{74}$ The regulatory authority lays down regulations and motions to meet the interests of the state or remove what is bad in its affairs in accordance with the Islamic Shari'a. ${ }^{75}$

\section{Analysis on implementation of Constitutional provisions}

Implementation of Constitutional provisions depends on the very nature or mentality of government. Sometimes Constitutional provisions are suspended due to emergency condition of the country ${ }^{76}$. In the case of Bangladesh Constitution the Islamic provisions are nothing but religious decoration. To see "Bismillahir Rahmanir Rahim" from the beginning of the Bangladesh Constitution doesn't signify that Bangladesh is an Islamic country. The Islamic provisions were inserted in the Constitution by the military government, as a majority people of Bangladesh are Muslims. "This was done necessarily with a political end. It was a constitutional tricks played by General Zia especially to get quick blind support from a large section of people who are religious but politically unconscious. Likewise one of four major fundamental principles of state policy "secularism" was omitted and in its place principles of absolute trust and faith in the Almighty Allah was inserted. This was also done with the same political end" ${ }^{\text {"77 }}$. To increase his popularity Ziaur Rahman set the provisions in Fifth Amendment in this way. ${ }^{78}$ On that account, Islamic provisions it is observed, in our Constitution is religious 


\section{The need of Uniform Islamic Constitution for the Muslim Ummah}

ornament but having no enforcing power, as there was no intention to impliment those provisions. Islam became state religion through eighth amendment by another military government headed by General Ershad. In the constitution of Bangladesh there are no provisions to exercise Islamic provision constitutionally, for example, collection of zakat or prohibiting riba, as mentioned above. Our economic system is based on riba (interest). Again, Article, 25 demands fraternal relations among Muslim Countries, but its application is not found properly rather deep relation is seen with the non-Muslims powerful states. Likewise in the Constitution of Pakistan there are many Islamic provisions but the rulers of Pakistan are not, so to say, practicing Muslims. Shiatis-Sunni violence is common sight in Pakistan, fraternal relation among Muslim states is not harmonious and present government of Pakistan is much inclined to UK, USA, antiIslamic states. Saudi Constitution is not properly Islamic as there is kingship, which is not supported by the Holy Quran, as mentioned above. Saudi government does not help the Muslim states against the atrocities of the Jews and Christians. Constitution of Iran bears Islamic features but it should also cover other aspects of universal nature, so that Muslim Ummah can be benefited.

\section{Conclusion}

At present uniform Islamic Constitution for the Muslim Ummah is imaginary simply because the relation among the Muslim states is not satisfactory healthy and harmonious. Though the color, culture, language and physical structure of the Muslims are different in different countries but all Muslims of the world read the same Quran and Hadith with same honour respect and religious emotion. So, Muslims should come under one platform of Islam. Political, economical, social, cultural difference cannot stand on the way of unification. By upholding the Quran and Sunnah firmly Muslim can reach at the golden age of Islam again as it was done under the leadership of Prophet Mohammad (sm). Muslims, at present, in the world is about 25\%, the number of states is 56 and about $46 \%$ wealth is possessed by the Muslim states. Under the circumstances, Muslim should be united against non-Muslims. This idea can help to a great extent, if all the Muslim states enact their Constitutions according to the provisions of Quran and Sunnah.

\section{Reference}

1. Chowdhury, Dilara (1995), Constitutional Development in Bangladesh(stresses \& strains), Dhaka:The University Press limited, p-1

2. Halim, Md. Abdul (1993), Constitution, Constitutional Law and Politics: Bangladesh Perspective, Dhaka: Md. Yousuf Ali Khan. 1st Edition P-26.

3. ibid.

4. Universal Standard Encyclopedia, v-6. (Cited from, Latifur Rahman ,Justice (2004), The Constitution of the People's Republic Bangladesh, with comment \&case Laws.), Dhaka: Mullick Brothers, P-8.

5. Aristotle (cited from Halim, Md. Abdul, Constitution, Constitutional Law and Politics: Bangladesh Perspective, Dhaka: Md. Yousuf Ali Khan, (1993) 1st Edition, p-26.

6. Coole, Treatise on Constitutional Limitations. (Cited from, Latifur Rahman, Justice, The Constitution of the People's Republic Bangladesh, with comment \&case Laws. Dhaka: Mullick Brothers, (2004) ,P-8. 


\section{IIUC Studies, Vol. 3}

7. Strong, C.F (1970), Modern Political Constitution ,London: ELBS p-11

8. Maududi, S. Abul A'la (1997), Islamic Law and Constitution, Lahore: Islamic Publication (pvt) Ltd, 12th edition, p-29.

9. Latifur Rahman, Justice (2004), The Constitution of the People's Republic Bangladesh, with comment \&case Laws, Dhaka: Mullick Brothers, p-29.

10. Maududi, S. Abul A’la (1997), Islamic Law and Constitution, Lahore: Islamic Publications (pvt) Ltd, 12th edition, p-203-204.

11. Encyclopedia Americana (1970), New York: Americana Corporation, v-23, p-391.

12. Encyclopedia Americana (1970), New York: Americana Corporation, v-24, p-521.

13. Abdur Rahim, Muhammad (2000), Rastro O Sarka) State and Government) ,Dhaka: Khairun Prokashani, 3rd Edition, p-143.

14. Sura Hazz, verse-41

15. Sura Qusas, verse 83

16. Sura Namal, verse-34

17. Sura Kahaf, verse- 89

18. Francis W. Coker, "Sovereignty”. Encyclopedia of Social Sciences, Vol-14, p. 265.

19. Edward MeChesney Sait (Ed.) (1949), Masters of Political Thought, Vol-11, London.

20. Maududi, S. Abul A’la (1997), Islamic Law and Constitution, Lahore: Islamic Publication(pvt)Ltd, 12th edition, p-212.

21. ibid, $\mathrm{p}-215$

22. Martin, Jacques (1955), Man and the State, Chicago. p-50-53.

23. Al-Qur’an, 11:107.

24. Ibid, 21:23.

25. Ibid, 23: 84-87.

26. Ibid,23:88.

27. Ibid, 59:23-24.

28. Ibid, 7:54

29. Ibid, $5: 45$

30. Ibid, $12: 40$

31. Ibid,7:3

32. Ibid, $5: 44$

33. Munir, Muhammad (1978), Constitution of Islamic Republic of Pakistan, Lahore: Law Publishing Company, 1st edition, p-3.

34. Ali, K. (1998), A Study of Islamic History, Dhaka, Mokurrum Publication, 24th Edition,pp-3738

35. ibid

36. Islam, Mahmudul (1995), Constitutional Law of Bangladesh, Dhaka: Bangladesh Institute of law and International Affairs,1st edition, p-13 
The need of Uniform Islamic Constitution for the Muslim Ummah

37. Preamble, The Constitution of the People's Republic of Bangladesh.

38. Fourth Amendment, The Constitution of the People's Republic of Bangladesh.

39. ibid

40. ibid, (preamble, second paragraph)

41. Article 2A, ibid 1988, which was inserted by the Constitution (Eight Amendment) Act 1988, Act no-xxx of

42. Article 8(1), ibid.

43. Article $8(1 \mathrm{~A})$, ibid.

44. Article 18(1), ibid.

45. Article 18(2), ibid.

46. Article 25(2), ibid

47. Preamble, The Constitution of the Islamic Republic of Pakistan.

48. Article-1, ibid.

49. Article-20, ibid.

50. Article-21, ibid.

51. Article-22, ibid.

52. Article-31, ibid.

53. Article-40, ibid.

54. Article-41(2), ibid.

55. Art -227 , ibid.

56. Munir, Muhammad (1978), Constitution of Islamic Republic of Pakistan, Lahore: Law Publishing Company, 1st edition, pp-40-41

57. Article-1, The Constitution of the Islamic Republic of Iran.

58. Article-2, The Constitution of the Islamic Republic of Iran.

59. Article-7, ibid.

60. Article-8, ibid.

61. Article-11, ibid.

62. Article-14, ibid.

63. Article-1, The Constitution of the Kingdom of Saudi Arabia

64. Article-5(b), ibid.

65. Article-7, ibid.

66. Article-8, ibid.

67. Article-9, ibid.

68. Article-11, ibid.

69. Article-17, ibid. 
IIUC Studies, Vol. 3

70. Article-23, ibid.

71. Article-26, ibid.

72. Article-38, ibid.

73. Article-45, ibid

74. Article-47,48,ibid.

75. Article-67, ibid.

76. Article-141B, The Constitution of the People's Republic of Bangladesh.

77. Halim, Md.Abdul (1993), Constitution, Constitutional Law and Politics: Bangladesh Perspective, Dhaka: Md. Yousuf Ali Khan, 1st Edition. pp-150-151.

78. Khan, Dr. Mohammad Maimul Ahsan (1998), Sangbidhanik Ain: Rajnetite Dharmo O Shadhinota (Constitutional Law: Religion and Freedom in Politics), Dhaka, Bishwa Sahittya Bhaban, p-358. 